Volume II, No.2 Desember 2012/1433 H

\title{
MEKANISME KLIRING PADA PERBANKAN KONVENSIONAL PERSPEKTIF ISLAM
}

\author{
Abdul Salam \\ (Dosen Ekonomi Syari'ah STIA Alma Ata Yogyakarta)
}

\begin{abstract}
Clearing is derived from English "to clear" meaning settlement, while the meaning of the clearing is good electronic financial data between banks or between the client resolved calculation results in a certain time. In the implementation of this clearing, clearing services client in this exploit is represented by the bank. Thus, in Islam the activity is often called as wakalah. The aim of this study is to find out how the mechanism clearing system running on Conventional Banks, and how Islamic outlook about the system, including categories of interest or not. In this research, the writer uses descriptive analysis method and more closer to study literature (library research) plus a little interview with employees of the Bank. The results of study that emphasize the study of this literature is the case of the grant of the bank overdraft services require customers to refund loan of approximately $5 \%$ above the highest rate in the bank in a month. In the same cases, Bank gives sanction to the customer to check for empty and termination of client giral blacklisted by a bank. This could be allowed under Islam law, due to before dropping the sanctions, warning that the banks were giving our customers don't draw a blank check anymore.
\end{abstract}

Keywords: Clearing Mechanism, wakalah, overdraft, Conventional Banks, Islamic perspective

\section{A. Pendahuluan}

Perbankan merupakan prasarana di bidang ekonomi, dalam segala kegiatan dalam rangka usaha-usaha pembangunan ekonomi digunakan prasarana perbankan. Setiap pembayaran atas biaya pembangunan dilakukan melalui bank yang usaha pokoknya memberikan jasa-jasa dalam lalu-lintas pembayaran dan peredaran uang di samping pemberian kredit (Anwar, 1982).

Dalam perkembangan perekonomian terutama sekali dalam

JESI

JURNAL EKONOMI SYARIAH

INDONESIA perkembangan perdagangan, uang tunai baik uang kertas maupun uang logam dirasakan mempunyai kelemahan dalam menyelesaikan transaksi tentang transaksi uang dalam jumlah besar di mana sejumlah uang tunai di atas harus dibawa-bawa sehingga beresiko tinggi terhadap keamanan dan kurang praktis. Terlebih lagi apabila jarak pihak-pihak yang bertransaksi jauh. Di sinilah kehadiran uang giral (rekening koran, BG, dan cek) sangat terasa manfaatnya. Uang giral yang dimaksud adalah demand deposit money 
yaitu uang yang ada di bank yang dapat diambil oleh si pemegang sewaktu-waktu (Sinungan, 1991).

Dalam hal tersebut bank memberikan suatu sarana yang dinamakan kliring, yang tujuannya adalah agar penyelesaian transaksi dapat dilakukan secara cepat, aman, efektif dan efisien (Taswin, 1997). Secara umum kliring adalah tata cara perhitungan atas penyelesaian hutang-piutang dalam bentuk surat-surat berharga dan surat-surat dagang dari suatu bank terhadap bank lainnya, yang bertujuan agar penyelesaiannya dapat terselenggara dengan mudah, cepat, dan aman serta untuk memperluas dan memperlancar lalu-lintas pembayaran giral. Sementara itu, lalu-lintas pembayaran giral di sini merupakan suatu proses kegiatan bayar membayar dengan warkat kliring yang dilakukan dengan cara memperhitungkan di antara bank-bank, baik atas beban maupun untuk keuntungan nasabah yang bersangkutan. Jadi untuk menyelenggarakan kliring harus ada penyelenggara, ada bank peserta, dan ada nasabah yang mempunyai hubungan hutang-piutang antar bank, serta ada warkat yang diperhitungkan.

Warkat kliring adalah alat atau sarana yang digunakan dalam lalulintas pembayaran giral yaitu surat berharga atau surat dagang seperti cek, BG, wesel bank untuk transfer/wesel unjuk, bukti-bukti transfer dari bank, nota kredit dan surat berharga lainnya yang disetujui oleh penyelenggara. Warkat yang dikliring harus memenuhi syarat yaitu bervaluta rupiah, bernilai nominal penuh, telah jatuh tempo pada saat dikliringkan, dan telah dibubuhi cap kliring.

Semua warkat itu telah dikelompokkan atas warkat debet dan warkat kredit. Bagi kantor-kantor bank yang menjadi peserta kliring langsung harus menunjuk sekurang-kurangnya 2 orang wakil tetap sebagai petugas kliring (clearingman) yang diajukan secara tertulis kepada penyelenggara kliring dan menyampaikan pula contoh tanda tangan dan paraf dari wakil tersebut. Penunjukan wakil itu baru berlaku setelah memperoleh persetujuan dari penyelenggara kliring (Rizal, 1992)

Pada dasarnya pelaksanaan kegiatan kliring yang dilakukan bankbank meliputi beberapa tahapan, yaitu penyetoran warkat kliring, pertemuan kliring pertama, pertemuan kliring kedua. Dalam tahapan penyetoran warkat kliring, bank menerima setoran warkat kliring nasabah serta mempersiapkan daftar kliring, rekapitulasi kliring, neraca kliring untuk pertemuan pertama. Pada waktu kliring pertama, bank menyerahkan dan menerima daftar kliring beserta warkat-warkatnya kepada dan dari masing-masing kantor bank peserta. Kemudian petugas kliring bank kembali ke kantor untuk memeriksa dan meneliti warkatwarkat kliring yang diterima serta mempersiapkan daftar kliring retur, rekapitulasi bank retur, dan neraca kliring retur untuk pertemuan kliring kedua. Pada tahap pertemuan kedua bank-bank menyerahkan dan menerima daftar kliring retur beserta warkat-warkat serta menandatangani saldo bilyat kliring (Rizal, 1992).

Dalam sistem kliring ini, fungsi cek untuk kegiatan kliring ini, yang bertransaksi ini adalah bank dan nasabah. Di antara pihak terjadi kesepakatan kliring, jika cek tersebut berisi berarti uang cair, dan jika giro kosong maka bank akan memberi tindakan seperti: Bagi nasabah yang 
sudah dikenal bank (bonafit) biasanya bank memberikan fasilitas yang bernama overdraft. Overdraft ini adalah dana jangka pendek yang diberikan bank kepada nasabah yang menurut bank dapat dipercaya. Dalam hal ini jangka waktunya paling lama satu sampai dua hari, apabila tidak mampu diberi kelonggaran paling lama tujuh hari.

Dalam pelaksanaan kliring sebenarnya menyimpan berbagai macam permasalahan. Diantaranya jika seorang nasabah melakukan penarikan cek kosong, untuk penarikan cek kosong ini bank melakukan melakukan beberapa tindakan bagi nasabahnya yaitu dengan memberikan jasa overdraft bagi nasabah tertentu atau memberi sanksi kepada nasabah setelah bank memberikan peringatan sebanyak dua kali, dan sangsi yang diberikan bank adalah berupa penutupan rekening giro dan masuk dalam daftar hitam bank Indonesia.

Dalam hal pemberian jasa overdraft ini bank mewajibkan nasabah mengembalikan dana pinjaman kurang lebih sebesar 5\% diatas bunga tertinggi di bank dalam satu bulan, sehingga menimbulkan perbedaan pendapat tentang kedudukannya apakah termasuk katagori riba atau bukan. Serta jasa ini dapat di manfaatkan bank untuk melakukan tindakan penipuan, pengambilan kesempatan dalam kesempitan dan unsur ketidakadilan.

Timbul masalah terhadap nasabah yang tidak mendapat fasilitas tersebut, bank akan memberikan tindakan berupa penutupan rekening giro dan kemudian dimasukkan dalam daftar hitam. Kemudian nasabah diminta biaya administrasi atas penarikan cek kosong tersebut.

\section{B. Konsep Wakalah dalam Islam}

\section{Pengertian dan dasar hukum}

Wakalah itu berarti perlindungan (al-hifz), pencukupan (al-ayah), tanggungan (al-daman) atau pendelegasian (al-tafd) yang diartikan juga dengan memberi kuasa atau mewakilkan (Suhendi, 2002). Adapun menurut kamus al-Munawwir kata _ _ berarti menyerahkan, mempercayakan, sedangkan kata berarti perwakilan. Adapun yang dikuasakan, menggantikan orang lain (Warsun, 1997).

Wakalah atau al-wakilah menurut istilah dapat dikatakan pemberian kuasa (wakalah) adalah suatu perjanjian di mana seseorang mendelegasikan atau menyerahkan sesuatu wewenang (kekuasaan) kepada orang lain untuk menyelenggarakan sesuatu urusan dan orang lain tersebut menerimanya dan melaksanakannya untuk dan atas nama pemberi kuasa.

Adapun yang menjadi dasar hukum diperbolehkan adanya wakalah ini dapat ditemukan dalam ketentuan al-Qur'an dan al-Hadis, ketentuan-ketentuan tersebut adalah :

Mekanisme

a) Surat Al-Kahfi (18) : 21

Kliring

b) Hadis Riwayat Muslim :

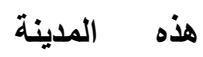

Berdasarkan hal-hal di atas, umat Islam telah sepakat akan kebolehan wakalah, karena hajat memang menghendakinya. Berwakalah

JURNAL EKONOMI SYARIAH INDONESIA, Volume II, No.2 Desember 2012 
itu merupakan salah satu bentuk tolong menolong dan memperlancar berbagai aktifitas manusia. Dalam lembaga wakalah terkandung unsurunsur untuk memudahkan berbagai kegiatan manusia dalam bermuamalah.

\section{Pihak-pihak yang berakad}

Dalam hal ini seorang 'aqid harus memenuhi prinsip kecakapan (ahliyah) melakukan akad untuk dirinya sendiri, atau karena mendapat kewenangan (wilayah) melakukan akad menggantikan orang lain atau berdasarkan perwakilan. Oleh karena itu, pada kesempatan ini penulis memandang perlu menyampaikan konsep ahliyah dan wilayah, meskipun hanya secara global.

a. Ahliyah

Merupakan istilah fuqaha dan ahli usul ahliyah yaitu kecakapan seseorang untuk memiliki hak dan dikenai kewajiban atasnya dan kecakapan untuk melakukan tasaruf. Dengan demikian ahliyah dibedakan menjadi dua ahliyah al-wujub dan ahliyah al-ada' (az-Zuhaili, 1989).

Ahliyah wujub (kecakapan memiliki hak) adalah kecakapan seseorang untuk mempunyai sejumlah hak kebendaan, seperti hak waris, hak ganti rugi atas kerusakan harta miliknya. Ahliyah al-wujub ini bersumber dari kehidupan dan kemanusiaan. Dengan demikian setiap manusia sepanjang masih bernyawa ia secara hukum dipandang cakap memiliki hak, sekalipun janin yang masih dalam kandungan ibunya (azZuhaili, 1989). Wilayah (kewenangan) untuk mentasarufkan harta orang lain dan melaksanakan akad untuk orang lain sesungguhnya merupakan tanggung jawab yang besar. Oleh karena itu, seorang wali (pemegang wilayah) baik wali pribadi seperti ayah, atau kakek, maupun wali publik seperti hakim, nadzir wakaf, ketua lembaga sosial dan lain sebagainya, ditetapkan atas mereka memenuhi beberapa syarat :

a) Cakap bertindak secara sempurna (baligh dan berakal sehat).

b) Adil, yakni istiqomah dalam menjalankan ajaran agama dan berakhlak mulia dan menjaga muru'ah.

c) Mampu melakukan tasaruf secara amanah.

d) Dalam bertasaruf selalu menjaga kepentingan orang yang dalam perwalian (Mas'adi, 2002).

Wilayah atau kewenangan untuk bertindak hukum dibedakan menjadi dua, kewenangan atas diri sendiri dan kewenangan bertindak hukum untuk orang lain yang dinamakan wilayah al-niyabah, seperti wilayah orang tua terhadap anaknya yang masih kecil, dan kewenangan berdasarkan wakalah.

Dengan tiga sebab menimbulkan kecakapan pada seseorang untuk dapat melakukan akad. Pertama ahliyatul ada' yang merupakan kewenangan yang timbul dari diri sendiri, kedua al-wilayah adalah kewenangan atas orang yang tidak memiliki ahliyatul ada' dan ketiga alwahakil merupakan kewenangan atas orang lain berdasarkan perwakilan (Mas'adi, 2002).

Adapun Ahliyatul ada' (kecakapan bertindak) adalah kecapan Abdul Salam seseorang untuk melakukan tasaruf dan dikenai pertanggungjawaban atas iltizam atau kewajiban yang berupa hak Allah maupun hak manusia. Sumber atau sandaran kecakapan ini adalah adanya sifat mumayyiz (dapat 
membedakan dua hal yang berbeda seperti antara baik dan buruk, benar dan salah dan sebagainya) dan berakal sehat.

Seorang mumayyiz yang berakal sehat cakap melakukan tasaruf, namun tidak cakap melakukan akad karena itu kecakapan bertindak seorang mumayyiz yang berakal sehat dinamakan Ahliyatul ada' al-maqishah (kecakapan bertindak yang tidak sempurna). Akad hanya dapat dilakukan oleh seseorang yang mempunyai kecakapan bertindak secara sempurna (ahliyatul ada' al-kamilah), yaitu orang yang telah mencapai usia baligh dan sempurna (Mas'adi, 2002).

b. Wilayah

Menurut istilah fuqaha dan ahli usul, wilayah adalah "kekuasaan hukum" (al-sulthan al-syafi'iyah) yang mana pemiliknya dapat bertasaruf dan melakukan akad dan menunaikan segala akibat hukum yang ditimbulkannya.

Kaitannya dengan akad, wilayah merupakan syarat kelangsungan akad dan syarat bagi timbulnya akibat hukum. Wilayah (kewenangan) melakukan akad tidak dimiliki kecuali oleh orang yang cakap bertindak secara sempurna. Sedangkan orang yang kecakapannya bertindak tidak sempurna tidak mempunyai wilayah baik atas dirinya sendiri maupun atas orang lain. Dengan demikian akad yang dilakukan oleh orang yang tidak mempunyai wilayah (kewenangan berakad) adalah tidak sah dan sama sekali tidak menimbulkan akibat hukum.

\section{Rukun dan Syarat Sahnya Pemberian Kuasa (Wakalah)}

Umumnya dalam praktek hukum dewasa ini, pemberian kuasa selalu dilakukan dalam bentuk "kuasa tertulis", seperti pemberian kuasa untuk mengurus suatu perkara di pengadilan, pemberian kuasa menjual, dan sebagainya.

Dalam praktek di Indonesia ada beberapa pemberian kuasa yang harus dilakukan secara tertulis (dimaksudkan untuk menghindari penyalahgunaan kekuasaan atau wewenang yang diberikan oleh pemberi kuasa).

Sedangkan untuk syarat sahnya suatu perwakilan haruslah dipenuhi syarat-syarat sebagai berikut :

a. Pemberi kuasa (muwakkil)

Orang yang memberi kuasa adalah orang yang mempunyai kekuasaan atau wewenang untuk itu, dan dia cakap melakukan perbuatan hukum, yaitu dewasa atau baligh, tidak gila atau kurang akal, dan tidak ditaruh dalam pengampuan.

b. Penerima kuasa (wakil)

Penerima kuasa adalah orang yang cakap dalam bertindak dalam hukum yaitu dewasa atau baligh, tidak gila atau kurang akal, dan tidak ditaruh dalam pengampuan.

Mekanisme

Kliring c. Obyek yang dikuasakan

Hal-hal yang dikuasakan (muwakkal fih) haruslah dapat diketahui oleh penerima kuasa dan dapat dikuasakan, sebab dalam Hukum Islam tidak semua hal dapat dikuasakan kepada pihak lain. Adapun yang boleh dikuasakan adalah semua perjanjian (akad) yang boleh diperbuat oleh 
manusia seperti sewa-menyewa, jual beli, membayar hutang, berperkara di depan pengadilan, berdamai, menghibah, sedekah, menggadaikan, pinjam meminjam, perkawinan, talak, mengurus harta dan lain sebagainya (Suhendi, 2002).

\section{Rusaknya Akad}

Hal-hal yang menyebabkan akad rusak karena tidak terpenuhi unsur-unsur suka rela antara kedua belah pihak. Hal-hal yang dipandang merusak terjadinya akad adalah (Basyir, 1993) :

\section{a. Paksaan}

Untuk sahnya suatu akad, harus terjadi dengan suka rela antara pihak-pihak yang bersangkutan. Unsur paksaan mengakibatkan akad yang dilakukan tidak sah.

b. Kekeliruan

Yang dimaksud kekeliruan di sini ialah kekeliruan yang terjadi pada obyek akad, bukan pada subyeknya juga. Sebab tentang subyek akad sudah dibicarakan dalam macam-macamnya, apakah seseorang bertindak sebagai subyek asli, mewakilkan orang lain atau lancang. Kekeliruan pada obyek akad mungkin terjadi pada jenisnya atau sifatnya. Kekeliruan dikatakan terjadi pada obyek akad apabila, misalnya seseorang melakukan jual beli cincin emas, tetapi ternyata cincin itu adalah cincin tembaga. Kekeliruan terjadi pada subyek akad, apabila misalnya seseorang mengadakan akad jual beli arloji merk tertentu, tetapi ternyata arloji lain, bukan yang diinginkan dan apabila sudah diketahui sebelumnya tidak akan terjadi akad tersebut. Apabila unsur suka rela antara dua pihak merupakan asas sahnya suatu akad maka terjadilah kekeliruan pada obyek akad itu akan menghilangkan unsur suka rela itu.

c. Penipuan

Yang dimaksud dengan penipuan atau pemalsuan disini adalah menyembunyikan cacat pada obyek akad agar nampak tidak seperti yang sebenarnya, atau perbuatan pihak penjual terhadap barang yang dijual dengan maksud untuk memperoleh harga yang lebih besar. Orang menjual kambing perahan, beberapa hari sebelumnya tidak diperas agar dikira air susunya amat deras, karena susunya pada waktu kambing dijual nampak amat penuh.

\section{d. Tipu muslihat}

Tipu muslihat dalam akad dapat terjadi apabila misalnya ada orang yang sedang menawar harga barang, tetapi oleh penjualnya ada seseorang yang sengaja dibuat menjadi calo untuk menawar lebih dari tawaran sebelumnya. Akhirnya ia mau membeli barang bersangkutan dengan harga lebih tinggi dari biasanya. Apabila hal itu terjadi, menurut para fuqaha Mazhab Syafi'i dan hambali, pembeli yang terkecoh berhak fasakh.

\section{Berakhirnya Perwakilan}

Suatu perwakilan dipandang telah berakhir dengan salah satu dan banyak hal, dan yang terpenting adalah hal-hal sebagai berikut (Basyir, 1993) :

a. Apabila maksud dari perwakilan telah selesai.

b. Apabila yang mewakilkan menangani sendiri hal yang diwakilkan kepada orang lain.

c. Apabila wakil dihentikan oleh yang mewakilkan. 
d. Apabila yang mewakilkan meninggal atau sakit gila yang parah.

e. Apabila wakil menarik diri akad perwakilan.

f. Apabila wakil kehilangan kecakapan sakit gila yang parah.

g. Apabila yang menjadi obyek perwakilan menjadi lenyap dan musnah.

Perwakilan dapat terjadi sebagai pemberian jasa tanpa imbalan dari wakil, dan dapat juga merupakan penjualan dari wakil kepada orang yang mewakilkan. Dalam hal perwakilan merupakan penjualan jasa, pihak yang mewakilkan dapat memberi syarat-syarat, misalnya tidak dapat menarik diri dalam batas waktu tertentu dan sebagainya. Apabila syarat-syarat yang telah menjadi persetujuan bersama itu dilanggar oleh wakil dia dapat dituntut ganti kerugian.

Akhirnya perlu disebutkan bahwa wakil adalah orang yang mendapat kepercayaan dari orang yang mewakilkannya. Oleh karenanya wakil tidak menanggung resiko atas kerugian orang yang mewakilkan kepadanya kecuali apabila atas kesengajaan dan kelengahannya.

C. Konsep dan mekanisme Kliring dalam perbankan konvensional 1. Pengertian Kliring

Arti kliring secara umum, menurut The New Gollier International Dictionary of English Language adalah : the act of exchanging draft on each other and settling the differences (kegiatan mempertukarkan warkat-warkat bank, suatu bank dengan bank-bank lainnya dalam menyelesaikan selisihnya) (Subagyo, 2002). Pengertian kliring diambil dari Bahasa Inggris, to clear, yang berarti menyelesaikan, yang kemudian dipertegas lagi dengan kata settling (Triyanto, 1996).

Kliring merupakan sarana atau cara perhitungan hutang piutang dengan bentuk surat-surat berharga atau surat dagang dari suatu bank peserta yang diselenggarakan oleh Bank Indonesia atau pihak yang ditunjuk BI (Taswan, 2003). Dengan kata lain, kliring adalah tata teknis lalu lintas giro antar bank, jadi bukan untuk simpanan.

Dengan menggunakan cek sebagai alat pembayaran, cek dapat berpindah pindah tangan. Tangan terakhir (pemegang cek terakhir) yang menginginkan uang tunai, datang ke bank untuk menukarkannya dengan terima uang cash. Atas dasar prinsip tersebut, terciptalah uang giral, yakni uang yang beredar di tangan masyarakat melalui saluran bank, di mana orang belum melihat uangnya sebelum membutuhkan sendiri. Tata laksana uang giral ini didasarkan atas kesempatan tukar menukar cek antar bank asal, dari naskah giro masing-masing bank dengan sentralisasi yang dipegang BI (Nugroho, 1979).

\section{Penyelenggara dan Tugasnya}

a. Penyelenggara

Kliring diselenggarakan oleh Bank Indonesia antara bank-bank di

Mekanisme Kliring suatu wilayah yang disebut "kliring lokal", yakni suatu lingkungan tertentu yang memungkinkan kantor-kantor tersebut memperhitungkan warkat-warkat dalam jadwal kliring yang telah ditentukan.

Tempat-tempat yang tidak terdapat kantor BI, maka penyelenggaraan kliring diserahkan kepada bank yang ditunjuk BI, yang harus memenuhi beberapa persyaratan, antara lain kemampuan 
administrasi, tenaga, pimpinan dan pelaksana, ruang kantor, peralatan komunikasi dan lain-lain. Disamping itu ada ketentuan-ketentuan khusus bagi bank pelaksana kliring, yakni :

a) Berkewajiban untuk melaksanakan penyelenggaraan kliring sesuai dengan peraturan perundangan yang berlaku.

b) Menyampaikan laporan-laporan tentang data-data kliring setiap minggu bersama-sama dengan laporan likuiditas mingguan kepada BI yang membawahi wilayah kliring yang bersangkutan.

c) Untuk mempermudah bank dalam penyelenggaraan kliring, dalam pengertian uang kartal, maka ditentukan bahwa hasil kliring hari itu dapat diperhitungkan pada rekening bank tersebut pada BI.

b. Tugas

a) Pada kliring 1

1) Menyusun neraca kliring penyerahan gabungan berdasarkan neraca kliring penyerahan yang disampaikan oleh seluruh wakil peserta.

2) Apabila wakil peserta belum hadir sampai batas waktu akhir jadwal kliring penyerahan yang ditetapkannya, maka penyelenggara akan melaksanakan kegiatan sebagaimana yang telah diatur dalam mekanisme kliring, kemudian apabila wakil peserta hadir sebelum kliring penyerahan dinyatakan berakhir, ketentuan yang belum dilaksanakan oleh petugas penyelenggara akan dilanjutkan oleh wakil peserta yang bersangkutan (Taswan, 2003).

b) Pada kliring 11

1) Menyusun neraca kliring pengembalian gabungan berdasarkan neraca kliring pengembalian yang disampaikan oleh seluruh wakil peserta, kemudian membubuhi tanda tangan dan nama jelas petugas penyelenggara pada neraca kliring pengembalian gabungan tersebut.

2) Mencocokkan antara neraca kliring penyerahan (pengembalian) gabungan yang disusun oleh penyelenggara dengan Bilyet Saldo Kliring (BSK) yang disusun panitia.

3) Menandatangani dan mencantumkan nama jelas petugas penyelenggara pada BSK rangkap 2, setelah terdapat kecocokan antara neraca kliring penyerahan/pengembalian gabungan dengan BSK (Taswan, 2003).

\section{Peserta dan Persyaratan Keikutsertaan Kliring}

\section{a. Peserta Kliring}

Peserta kliring adalah bank atau Bank Indonesia yang terdaftar pada penyelenggara untuk mengikuti kliring. Peserta kliring

dikelompokkan menjadi :

1) Peserta langsung

Peserta langsung adalah peserta yang turut serta dalam pelaksanaan kliring secara langsung dengan menggunakan identitasnya sendiri. Peserta langsung dapat terdiri kantor pusat, kantor cabang, dan kantor cabang pembantu yang tidak berada dalam wilayah kliring dengan kantor induknya. Untuk menjadi peserta kliring langsung, harus memenuhi syarat : 
a) Kantor bank yang dapat menjadi peserta langsung adalah :

- Kantor cabang yang telah memperoleh ijin pembukaan kantor dari Bank Indonesia.

- Kantor cabang pembantu dari bank yang kantor pusatnya berkedudukan di luar negeri yang telah memperoleh ijin pembukaan kantor dari Bank Indonesia

- Kantor cabang pembantu dari bank yang kantor pusatnya berkedudukan di dalam negeri yang telah memperoleh ijin dari Bank Indonesia untuk beroperasi di wilayah kliring yang berbeda dari kantor cabang induknya.

b) Kantor bank mempunyai kantor lain yang mewakili rekening giro di salah satu kantor Bank Indonesia.

c) Lokasi kantor bank memungkinkan bank tesebut utnuk mengikuti kliring secara tertib sesuai jadwal kliring lokal yang ditetapkan. Dalam hal ini yang perlu dipertimbangkan adalah waktu tempuh dari lokasi kantor bank ke lokasi penyelenggara maksimal 45 menit.

2) Peserta tidak langsung

Peserta tidak langsung adalah peserta yang turut serta dalam pelaksanaan kliring melalui dan menggunakan identitas peserta langsung yang menjadi induknya yang merupakan bank yang sama. Peserta tidak langsung bisa terdiri dari kantor pusat, kantor cabang dan kantor cabang pembantu.

Untuk menjadi peseta tidak langsung, harus memenuhi persyaratan :

a) Kantor bank yang dapat menjadi peserta tidak langsung adalah :

- Kantor cabang yang telah memperoleh izin pembukaan kantor dari Bank Indonesia.

- Kantor cabang pembantu dari bank yang kantor pusatnya berkedudukan di luar negeri yang telah memperoleh ijin pembukaan kantor dari Bank Indonesia.

- Kantor cabang pembantu dari bank yang kantor pusatnya berkedudukan di dalam negeri yang telah telah dilaporkan kepada Bank Indonesia.

b) Kantor cabang sebagaimana dimaksud pada huruf a, menginduk kepada kantor lain yang merupakan bank sama yang telah menjadi peserta langsung di wilayah kliring yang sama (Taswan, 2003).

b. Syarat-syarat Bank Menjadi Peserta Kliring

1) Bank-bank yang telah mendapat izin dari menteri keuangan dan mendapat persetujuan dari Bank Indonesia terlebih dahulu.

2) Bank tersebut telah memenuhi penilaian sebagai bank yang sehat, baik ditinjau dari bidang administrasi, pimpinan maupun keuangan

Mekanisme

Kliring

3) Bank tersebut telah menjalankan usahanya minimal 3 bulan atas ijin Menteri Keuangan.

4) Simpanan masyarakat dalam bentuk giro dan kelonggaran tarik kredit yang diberikan oleh kantor tersebut telah mencapai sekurangkurangnya $20 \%$ dari syarat modal disetor bagi minimum pendirian bank baru di wilayahnya.

JURNAL EKONOMI SYARIAH INDONESIA, Volume II, No.2 Desember 2012 
5) Bank peserta kliring wajib membuka rekening Koran di Bank Indonesia.

6) Bank yang tidak tercatat sebagai peserta dapat ikut serta secara tidak langsung melalui pengikutsertaannya dengan bank lain (peserta). Penyertaan secara tidak langsung tersebut dapat terjadi karena bank kemungkinan menghadapi masalah keuangan, jarak antara bank yang bersangkutan dengan penyelenggara kliring, dan lain-lain.

7) Menyetor jaminan kliring sebesar $50 \%$ rata-rata kewajiban 20 hari terakhir dikurangi $40 \%$ rata-rata tagihan harioan 20 hari terakhir. Kewajiban tersebut hanya baerlaku bagi kantor bank yang baru menjadi peserta kliring atau yang baru direhabilitasi. Kewajiban menyetor jaminan kliring ini tidak berlaku bagi peserta tidak langsung atau peserta yang pindah wilayah kliring.

8) Bank peserta menentukan anggotanya sebagai wakil tetap pada lembaga lembaga kliring dan memberitahukan secra tertulis kepada Bank Indonesia (Subagyo, 2002).

\section{Jenis-jenis Warkat Kliring}

Warkat kliring adalah alat atau sarana yang digunakan dalam lalu lintas pembayaran giral (surat-surat berharga atau suraat dagang seperti cek, BG, wesel bank untuk transfer/wesel unjuk, bukti-bukti penerimaan transfer dari bank-bank, nota kredit dan surat-surat lainnya, yang disetujui oleh penyelenggara. Warkat yang dikliringkan harus memenuhi syarat yaitu bervaluta rupiah, bernominal penuh, telah jatuh pada saat dikliringkan dan telah dibubuhi cap kliring.

Dilihat dari jenisnya, maka warkat kliring dapat dibedakan menjadi 4 macam, yakni :

a. Warkat debet keluar

Yaitu warkat bank lain yang disetorkan oleh nasabah sendiri untuk keuntungan rekening nasabah yang bersangkutan. Bank penarik akan mendebet giro BI dan mengkredit rekening giro nasabah. Misalnya, Amin adalah nasabah Bank Maxi Semarang, menerima pembayaran Amir, nasabah Bank Mitra Niaga Semarang berupa cek. Cek tersebut disetorkan oleh Amin ke Bank Maxi, maka cek tersebut dapat dikatakan sebagai warkat debet keluar.

b. Warkat debet masuk

Yaitu warkat yang diterima oleh suatu bank dari bank lain melalui BI atas warkat/cek sendiri yang ditarik oleh nasabah sendiri dan atas beban nasabah yang bersangkutan. Bank penerima akan mendebet rekening giro nasabah dan mengkredit rekening giro BI. Misalnya, bila Bank BMM Semarang menerima cek dari Bank BPD Semarang atas cek yang ditarik oleh Andi, nasabah sendiri, maka cek tersebut merupakan warkat debet masuk bagi Bank BMM.

c. Warkat kredit keluar

Yaitu warkat dari nasabah sendiri untuk disetorkan kepada nasabah bank lain pada bank lain. Bank menyerahkan warkat tersebut akan mengkreditkan rekening giro BI dan mendebet giro nasabah.

Abdul

Salam

d. Warkat kredit masuk 
Yaitu warkat yang diterima oleh bank untuk keuntungan rekening nasabah bank tersebut. Bank yang menerima warkat tersebut akan mendebet rekening biro BI dan mengkredit giro nasabah (Taswan, 2003).

Warkat-warkat yang tidak dapat diperhitungkan dalam kliring :

a. Warkat-warkat yang belum memenuhi syarat sebagai warkat kliring.

b. Penyetoran warkat kepada penyelenggara untuk keperluan penyelesaian saldo negatif atau saldo debet.

c. Penyetoran warkat pada penyelenggara untuk pelaksanaan transfer dalam rangka pelimpahan likuiditas dari suatu peserta kepada kantorkantor cabangnya yang lain.

d. Penyetoran-penyetoran lain yang ditetapkan oleh BI berdasar kebutuhan (Taswan, 2003).

Warkat-warkat yang diperhitungkan dalam kliring adalah :

a. Cek

Adalah warkat yang berisi perintah tidak bersyarat kepada bank yang memelihara rekening nasabah untuk membayarkan suatu jumlah uang tertentu kepada atau kepada pembawanya.

b. Wesel

Adalah suatu surat yang mencantumkan kata "wesel" yang diterbitkan pada tanggal dan tempat tertentu di mana penerbit memerintah tanpa syarat kepada pihak yang ditunjuk untuk membayar sejumlah uang kepada pemegang atau penggantinya pada tempat dan tinggal yang telah ditetapkan. Dengan demikian wesel bank dapat diartikan sebagai suatu surat berharga yang dikeluarkan oleh bank penarik atau drawer dan merupakan perintah tidak bersyarat kepada bank atau kantor bank yang telah ditunjuk tertarik, atau drawee untuk membayarkan sejumlah uang kepada seseorang atau badan usaha tertentu, yang namanya tercantum dalam surat perintah atau wesel itu.

c. Bilyet giro

Merupakan surat perintah dari nasabah kepada bank yang memelihara rekening giro nasabah tersebut untuk memindahbukukan sejumlah uang dari rekening yang bersangkutan kepada pihak penerima yang disebutkan namanya pada bank yang sama atau bank lainnya.

d. Surat bukti penerimaan transfer

Yakni surat bukti penerimaan transfer dari luar kota yang dapat ditagihkan kepada bank peserta penerima dana transfer melalui kliring lokal.

e. Nota debet

Yakni warkat yang digunakan untuk menagih dana pada bank lain untuk untung baik atau nasabah bank yang menyampaikan warkat tersebut. Nota debet yang dikliringkan hendaknya telah diperjanjikan

Mekanisme

Kliring dan dikonfirmasikan terlebih dahulu oleh bank yang menyampaikan nota debet kepada bank yang akan menerima nota debet tersebut.

f. Nota kredit

Yakni nota warkat yang digunakan untuk menyampaikan dana pada bank lain untuk untung bank atau nasabah bank yang menerima warkat tersebut (Taswan, 2003). 


\section{Overdraft}

Overdraft adalah pemberian fasilitas oleh bank kepada nasabahnya berupa pelampauan penarikan atas saldo rekening giro yang tersedia secara efektif atau atas maksimum pinjaman berdasarkan akad kredit tanpa pemenuhan formalitas pinjaman terlebih dahulu (Anwari, 1985). Yang dimaksud dengan maksimum pinjaman adalah jumlah kredit yang disediakan oleh bank bagi nasabah sebagaimana tercantum dalam akad kredit yang bersangkutan.

Agar pemberian fasilitas cerukan (Triyanto, 1996) oleh bank-bank tersebut dapat dilakukan dengan tetap memperhatikan asas-asas perbankan yang sehat serta memberi manfaat yang positif pada dunia usaha, maka direksi Bank Indonesia dengan surat keputusan No.12/39/Kep/Dir/UPBB tanggal 20 Juli 1979 telah membuat ketentuan baru mengenai pemberian fasilitas overdraft oleh bank-bank.

Sehubungan dengan surat keputusan tersebut, ketentuan-ketentuan pelaksanaan serta penjelasannya adalah sebagai berikut :

a. Yang termasuk dalam pengertian cerukan ini adalah :

1) Cross clearing kepada nasabah yang bersangkutan diberikan kesempatan untuk melakukan penarikan pada hari yang sama atas dana yang berasal dari warkat-warkat kliring yang sedang ditagihkan.

2) Penarikan dana oleh nasabah atas warkat-warkat yang bukan tunai yang masih harus ditagihkan di luar kliring.

b. Bank tidak akan memberikan jasa overdraft ini kepada setiap nasabah, hanya nasabah tertentu saja yang memenuhi syarat sebagai berikut (Triyanto, 1996) :

1) Bonafid.

2) Layak mendapat kredit.

3) Telah dikenal oleh bank.

4) Jujur.

5) Patuh pada ketentuan-ketentuan di bidang perbankan.

6) Mempunyai kemampuan untuk melunasi cerukan dalam batas waktu yang ditetapkan.

c. Jangka waktu pemberian overdraft paling lama 7 hari.

d. Bank akan memungut bunga cerukan sebesar $1 \%$ di atas suku bunga tertinggi perbankan yang berlaku pada hari yang bersangkutan.

e. Jumlah fasilitas overdraft dapat diberikan kepada para nasabah adalah sebagai berikut:

1) Bagi nasabah giro, sebesar $10 \%$ dari saldo giro yang tersedia secara efektif pada data terjadinya cerukan.

2) Bagi nasabah debitur, sebesar $5 \%$ dari maksimum pinjaman yang diberikan berdasarkan akad kredit.

3) Mengingat bahwa pemberian fasilitas cerukan tidak didukung oleh akad kredit atau jaminan-jaminan yang dikuasakan oleh bank, maka pemberian fasilitas ini pada hakekatnya mengandung resiko yang cukup besar bagi bank yang bersangkutan, karena itu bank secara intern supaya menetapkan tata cara dan batas-batas kewenangan pemberian fasilitas overdraft.

4) Dalam hal pemberian fasilitas overdraft melebihi batas maksimum, maka yang bersangkutan dikenai sanksi $2 \%$ sebulan dari kelebihan 
cerukan di atas jumlah maksimum yang ditetapkan tersebut (Anwari, 1985).

Dalam pemberian fasilitas ini, izin overdraft tidak dapat terus menerus, artinya nasabah yang menarik overdraft harus menutup overdraftnya dalam waktu yang relatif singkat, apabila tidak secepatnya diselesaikan, maka nasabah mendapat sanksi (Siregar, 1984).

Perkembangan usaha nasabah tercantum dalam mutasi rekening itu sehingga mudah bagi bank untuk mengikuti pergerakan usaha nasabah. Dalam kredit rekening koran bebas ini maka kegiatan usaha nasabah tertera dalam mutasi kredit dan mutasi debet dari rekening pinjaman yang bersangkutan (Siregar, 1984).

6. Mekanisme Kliring dalam Bank Konvensional

Pada dasarnya kegiatan kliring yang dilakukan bank-bank meliputi beberapa tahapan yaitu penyetoran warkat kliring, pertemuan kliring pertama dan pertemuan kliring kedua. Mekanisme kegiatan kliring dapat digambarkan dalam bagan sebagai berikut :

\section{Gambar I \\ FLOWCHART KLIRING SEBELUM OTOMASI}

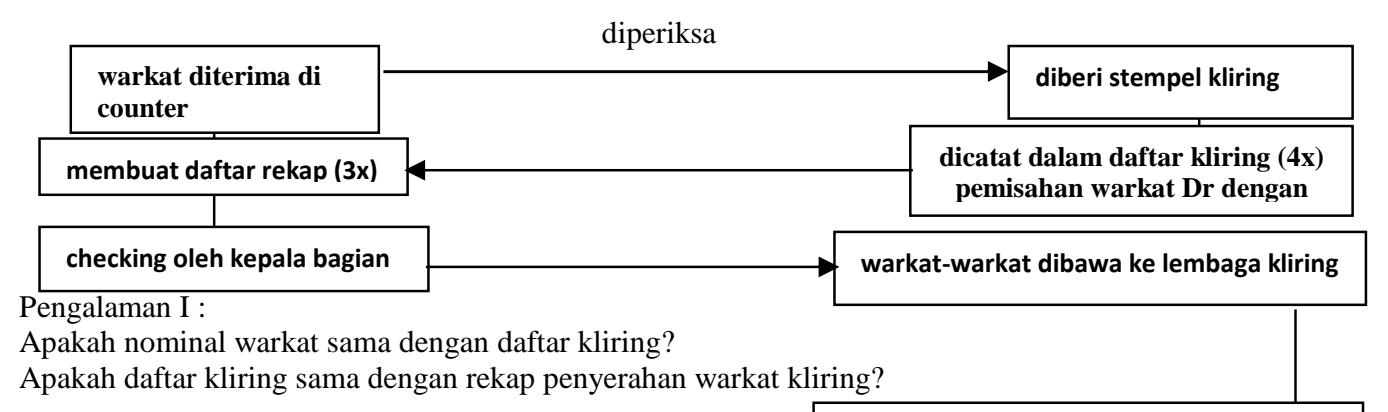

KLIRING I :

penyerahan/penerimaan warkat kliring

Pengalaman II :

Yang meyerahkan warkat kliring Yang menerima warkat kliring

petugas kliring kembali ke kantor

Pengalaman III :

Apakah jumlah warkat sesuai dengan banyaknya lembar yang tercantum dalam warkat penerimaan demikian pula dengan nominalnya?

KLIRING II :

Pengalaman IV :

Mekanisme

Petugas kliring menunggu sampai

Kliring

perhitungan kliring selesai

konfirmasi saldo $\mathrm{R} / \mathrm{K}$

- verifikasi tanda-tanda

- konfirmasi dengan nasabah

- membuat tolakan kliring

membuat bilyet saldo yang disahkan pimpinan lembaga kliring

petugas kliring kembali ke kantor

membuat neraca kliring

berdasar daftar rekapitulasi penyerahanpenerimaan (Dr.Cr tolakan) 
Gambar II

PROSEDUR PELAKSANAAN KLIRING

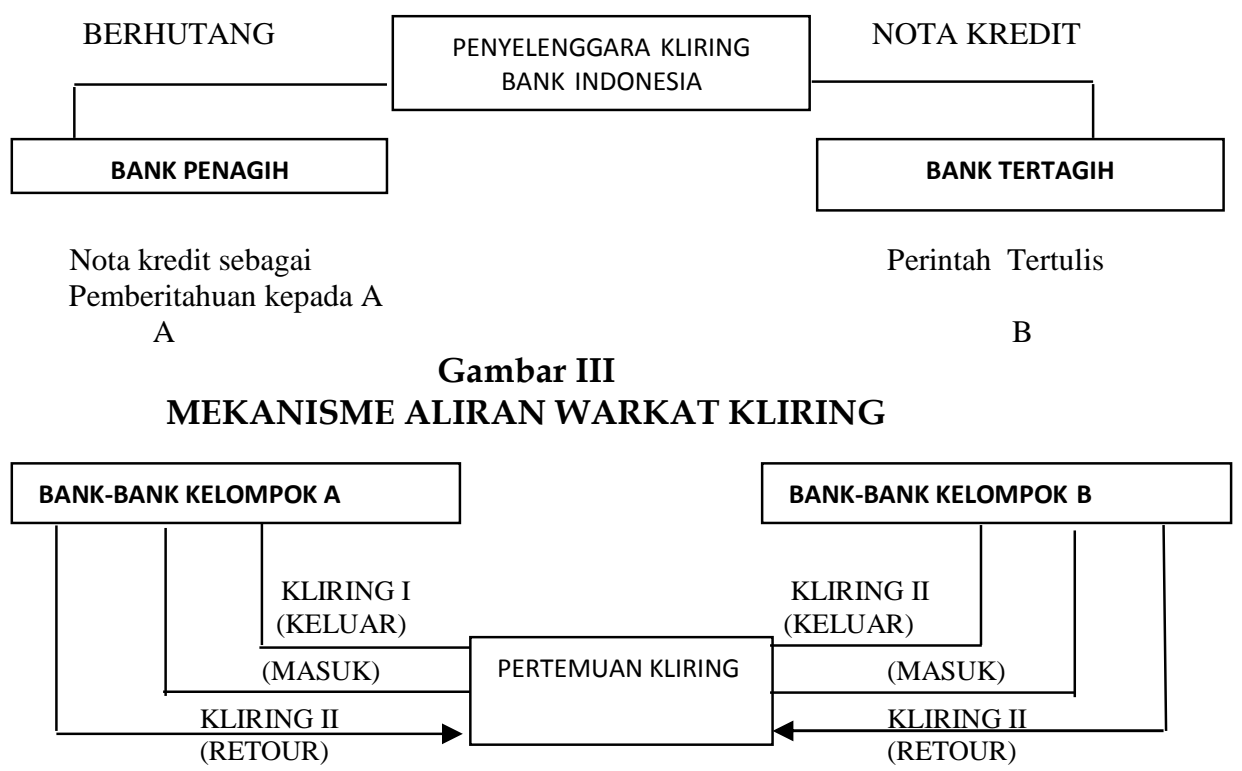

\section{Analisis Ekonomi Islam Terhadap Mekanisme Kliring Pada Perbankan Konvensional}

\section{Dari Segi Akad}

Jasa yang diberikan oleh suatu lembaga kliring, didasarkan atas kepercayaan, dengan demikian pemberian fasilitas ini merupakan pemberian kepercayaan, berarti suatu lembaga kliring baru akan memberikan fasilitas ini kalau betul-betul yakin bahwa penerima fasilitas ini akan menggunakan fasilitas atau jasa ini sesuai dengan waktu dan syarat-syarat yang telah disetujui oleh kedua belah pihak.

Setelah pihak bank (wakil) mengetahui dengan mempercayai akan kecakapan nasabah (muwakkil), maka dibuatlah suatu perjanjian yang dipergunakan sebagai landasan bagi kedua belah pihak dalam melakukan kerjasama penggunaan jasa tersebut. Perjanjian tersebut nantinya mengikat kedua belah pihak yaitu bank sebagai penyedia jasa kliring (wakil) dan nasabah sebagai pengguna jasa bank (muwakkil).

Dalam hukum Islam, transaksi atas perjanjian tersebut disebut Akad. Akad berasal dari bahasa arab يقا - ي - yang berarti menyimpulkan atau mengikat (Warsun, 1997). Pengertian akad secara bahasa oleh Hasbi ash-Shiddieqy adalah mengumpulkan dua tepi tali dan mengikat salah satunya dengan yang lain hingga bersambung kemudian keduanya menjadi sepotong benda (ash-Shiddieqy, 1984).

Menurut istilah, akad adalah perikatan antara ijab dengan qabul secara yang dibenarkan syara' yang menetapkan keridhoan kedua belah pihak. Menurut Azhar Basyir, menyebabkan adanya akibat-akibat hukumnya pada objeknya (Basyir, 1984). Sedangkan menurut Wahbah AzZuhaili, akad adalah setiap perbuatan yang dimaksudkan seseorang, baik yang berasal dari keinginan sepihak seperti wakaf, hibah, qirad dan sebagainya (Az-Zuhaili, 1989).

Abdul

Salam 
Ijab adalah perikatan khusus yang menerangkan iradat pihak yang pertama dari orang yang melakukan akad, sedangkan qabul adalah perbuatan pihak kedua dari orang yang melaksanakan akad, yang menerangkan kerelaan dan kesepakatan dari tujuan perkataan pihak pertama (Az-Zuhaili, 1989).

Akad terjadi secara suka rela antara dua pihak dan menimbulkan kewajiban dari masing-masing pihak secara timbal balik. Pada dasarnya akad sebagai persetujuan terjadinya perikatan mencakup segala tindakan manusia yang dilaksanakan dengan niat dan keinginan yang kuat untuk melaksanakan suatu perbuatan meskipun hanya merupakan tindakan sepihak.

Selanjutnya Hasbi Ash-Shiddieqy menegaskan bahwa rukun akad adalah ijab dan qabul yang disebut dengan sigat al aqdi atau ucapan atau perbuatan yang menunjukkan kepada kehendak kedua belah pihak (ashShiddieqy, 1984). Sigat al-aqdi merupakan rukun akad yang terpenting karena melalui pernyataan inilah diketahui maksud setiap pihak yang melakukan akad (Haroen, 1984).

Sigat al-aqdi mempunyai beberapa bentuk, yaitu dengan ucapan (perkataan), perbuatan (saling memberi dan menerima), dengan isyarat dan tulisan (Az-Zuhaili, 1989).

Jika akad telah berlangsung dan terpenuhinya rukun dan syaratsyaratnya, maka akad mempunyai akibat-akibat hukum yang harus diikuti dan dilaksanakan oleh pihak-pihak yang melakukan akad. Dalam akad yang objeknya benda dalam hal ini cek, akibat hukumnya adalah pihak muwakkil (nasabah) menyerahkan cek kepada bank dan bank (wakil) menerima cek tersebut dari nasabah sesuai dengan jumlah yang telah disepakati, sehingga masing mereka halal mengambil manfaat dan mempergunakannya di jalan yang dibenarkan syari'ah. Termasuk dalam akad ini adalah wakalah yang baru bersifat sempurna apabila telah dilakukan serah terima objek akad. Disebut pula dengan 'uqud'ainiyah, karena transaksi yang objeknya benda tersebut disyaratkan harus adanya barang yang diserahkan kepada pihak yang berhak dan dikuasai sepenuhnya (qabad) (As-Syairazi, tt).

Agar akad mempunyai kekuatan hukum yang kuat, maka hendaklah pelaksanaannya ditulis dan disaksikan oleh saksi, terutama akad yang berlaku untuk jangka waktu lama, seperti utang piutang atau transaksi kredit, gadai dan sebagainya dengan tujuan menjaga kepentingan hak dan kewajiban masing-masing. Firman Allah surat al-baqarah ayat 282:

Mekanisme Kliring
Secara tekstual lafaz merupakan perintah yang mempunyai

$$
\text { وليكتب بينكم }
$$
arti petunjuk dan kandungan dari ayat tersebut adalah barang siapa mengadakan akad perjanjian hendaklah dilakukan pencatatan (al-Maragi, $\mathrm{tt})$.

Pancatatan ini dilaksanakan untuk mendapatkan bukti otentik untuk melindungi kepentingan kedua belah pihak dari pelanggaran terhadap kesepakatan dalam akad oleh pihak-pihak tertentu untuk mendapatkan keuntungan secara sepihak. 
Dengan demikian, kedudukan akad merupakan syarat sah transaksi wakalah dan fungsinya sebagai pemindahan hak dan kewajiban dari nasabah (muwakkil) kepada bank (wakil) sesuai dengan kesepakatan antar kedua belah pihak.

Berdasarkan penelitian, kerjasama antara bank dan nasabah diperbankan konvensional adalah perjanjian dimana pihak bank menyediakan jasa transfer (melalui lembaga kliring) dengan menggunakan cek bagi nasabah, dan jasa itu akan digunakan oleh nasabah guna menyelesaikan transaksi sesuai dengan waktu atau tanggal yang dikehendaki oleh nasabah (muwakkil).

Akad terjadi ketika nasabah mengajukan diri sebagai nasabah giro dan bank memberikan formulir yang harus di isi oleh nasabah, yang berisi tentang syarat-syarat nasabah giro. Jika formulir telah di isi oleh nasabah dan disetujui oleh bank ditandai dengan ditandatanganinya formulir oleh kedua belah pihak, maka dengan sendirinya akad terjadi.

Apabila dilihat dari perspektif Hukum Islam, akad kerjasama yang terjadi ini dapat dikategorikan sebagai akad wakalah yang objeknya benda yaitu cek atau Bilyet Giro.

Ijab dan qabul yang merupakan rukun terpenting dalam akad mempunyai persyaratan tertentu, yaitu jelasnya pengertian yang dimaksudkan sehingga dalam persyaratan tersebut dapat dipahami jenis akadnya, adanya kesesuaian antara ijab dan qabul dalam satu majelis akad.

Berdasarkan penelitian literatur lebih lanjut, ijab qabul yang dipraktekkan dalam pemberian jasa transfer melalui lembaga kliring oleh bank kepada nasabah bank berupa akad dengan tulisan, yang diwujudkan dalam bentuk cek dan slip setoran. Akad dilakukan antara pihak nasabah dan bank yang diwakili oleh bagian customer.

Di dalam cek tersebut memuat beberapa hal penting yang berkaitan dengan maksud (iradah) dari pihak nasabah di antara identitas nasabah, jumlah dana yang ditarik dan tanggal pencarian.

Cek sebelum dikliringkan, bank biasa membuat slip setoran yang berisi tentang identitas tertarik, identitas si penarik, tujuan atau bank yang ditagih dalam kliring. Slip ini biasa rangkap empat, yang salah satunya diberikan kepada si penarik yang gunanya untuk menarik dana apabila proses kliring sudah selesai atau telah dilakukan kliring terhadap cek tersebut. Slip setoran ini diberikan kepada kedua belah pihak, sebagai bukti bahwa di antara kedua belah pihak telah terjadi kesepakatan kerjasama dalam jasa kliring. Serta sebagai bentuk autentik untuk menghindari hal-hal yang merugikan salah satu pihak yang berakibat pada rusaknya akad.

Adapun syarat-syarat sah wakalah dalam Hukum Islam adalah sebagai berikut :

Syarat pertama, pihak yang melaksanakan akad telah balig dan berakal (dewasa), yaitu mereka dapat melakukan perjanjian dengan pikiran yang sehat atau orang tersebut diistilahkan orang yang cakap untuk melaksanakan hukum. Manajer bank atau wakilnya dan nasabah, mayoritas telah berumah tangga, dan disamping itu rata-rata nasabah memakai barang bukti KTP untuk menjadi nasabah di bank tersebut. Orang baru bisa mempunyai KTP jika sudah berumur 17 tahun, dalam usia

Abdul

Salam

202

JURNAL EKONOMI SYARIAH INDONESIA, Volume II, No.2 Desember 2012 
17 tahun tersebut dalam Islam sudah disyaratkan baligh dan cakap bertindak hukum.

Syarat kedua obyek akad berupa barang yang dapat diukur atau diketahui jumlah maupun nilainya. Disyaratkannya hal ini agar waktu pembayarannya tidak menyulitkan. Dalam praktek atau mekanisme kliring ini, obyek akadnya berbentuk cek yang akan digunakan untuk menarik uang.

Sesuai dengan syarat tersebut di atas, tentang obyek akad maka uang merupakan salah satu bentuk obyek akad yang diperbolehkan karena dapat diketahui jumlah maupun nilainya dan dapat memudahkan bank dalam melakukan tugasnya.

Syarat ketiga, pernyataan ijab qabul baik pernyataan dari pihak nasabah (muwakkil) maupun dari pihak bank (wakil). Dalam mekanisme kliring ini, sebagaimana disebutkan di atas diwujudkan dalam bentuk tulisan. Hal ini berkaitan dengan adanya bentuk akad yang memerlukan waktu yang tidak lama dan tidak secara tunai. Dengan cek itu diisi oleh nasabah dan disetujui oleh pihak bank, secara otomatis telah ada lafal atau pernyataan dari kedua belah pihak untuk melaksanakan akad.

Akad yang dilakukan antara dua orang yang berjalan tempatnya dalam bentuk tulisan, sama juga dengan akad dengan lidah yang dilakukan oleh mereka yang sama-sama hadir dalam satu tempat. Hal ini disandarkan pada kaidah :

$$
\text { (al-Abidin, 1993) }
$$

Artinya pernyataan jelas yang dituangkan dalam bentuk tulisan. Kekuatan hukunnya sama dengan ungkapan langsung melalui lisan. Perbuatan yang dilakukan oleh kedua orang tersebut yaitu berakad dengan menggunakan tulisan yang terang dan jelas dapat diistilahkan dengan mustabinah marsumah (Amin, $\mathrm{tt}$ ).

Berdasarkan uraian tersebut di atas, maka kerjasama pihak bank dengan nasabah di perbankkan konvensional adalah sah menurut Hukum Islam, meskipun dalam pelaksanaannya terdapat beberapa hal yang terkadang dapat merusak sahnya suatu akad. Hal tersebut di antaranya dengan adanya nasabah yang mengingkari akad seperti pembayaran dengan cek kosong, sehingga adanya sanksi dari bank untuk nasabah, di samping itu adanya fasilitas overdraft yang diberikan bank kepada nasabah tertentu dengan jangka waktu yang pendek. Untuk masalah ini akan diuraikan tersendiri dalam analisis berikutnya.

Akad kerjasama dalam bentuk pemberian jasa bank, dalam hal ini melalui kliring sepenuhnya sah dengan didasari beberapa pertimbangan sebagai berikut :

Mekanisme Kliring
1) Nasabah bank pengguna jasa ini, sebagian besar merupakan pengusaha yang memerlukan jasa ini, sehingga dengan jasa ini dapat membantu memperlancar pembayaran di samping itu nasabah memperoleh kemudahan dalam bertransaksi.

2) Adanya prinsip kebersamaan dan tolong menolong antara bank dan nasabah. Kerjasama antara bank dan nasabah dalam bentuk kerjasama 
pemberian jasa memperlancar pembayaran yang dilakukan oleh nasabah.

\section{Dari Segi Jasa dan Overdraft}

Pada zaman sekarang, hampir kebanyakan transaksi hutang untuk kegiatan produktif dikenakan adanya bunga, sebab uang yang menjadi subjek dalam transaksi hutang-piutang tersebut digunakan untuk mencari keuntungan sehingga pemberi hutang merasa berhak memperoleh bagian hutang.

Hak ini dapat dipahami oleh orang yang setidaknya tahu tentang perekonomian. Dalam alam ekonomi, bank tidak mungkin meminjamkan uang kepada orang lain untuk kegiatan produktif begitu saja, tetapi dalam memberikan pinjaman, orang tersebut mempunyai maksud agar uang tersebut kembali disertai keuntungan.

Dalam kliring ada suatu fasilitas yang diberikan kepada nasabah tertentu, yang dianggap bonafit oleh bank, yang digunakan untuk mengatasi atau menutupi kekalahan dalam kliring. Overdraft adalah salah satu jenis transaksi perkreditan antara nasabah dan bank. Kredit ini merupakan modal bagi nasabah untuk usahanya yang notabene sebagai golongan menengah ke atas. Dalam pemberian kreditnya bank memberikan ketentuan dan prosedur yang harus dilaksanakan oleh nasabah berkaitan dengan transaksi tersebut adalah kewajiban bagi nasabah pemakai dana tersebut. Untuk mengembalikan kredit sesuai dengan waktu dan jumlah kredit yang ditetapkan. Besarnya pengembalian adalah sebesar $1 \%$ di atas kredit tertinggi di bank tersebut yang biasanya untuk di daerah Yogyakarta sebesar 5\% (Wawancara dengan karyawan Bank Konvensional). Pemberian fasilitas overdraft ini pada saat meminta fasilitas tersebut diminta untuk membayar biaya administrasi, biaya provisi,1) dan bunga.

Adanya ketentuan bahwa uang yang dipinjamkan harus dikembalikan dengan disertai tambahan berupa bunga, menimbulkan problem tersendiri dalam masyarakat dan masyarakat muslim pada khususnya. Problem tersebut menimbulkan berbagai pendapat yang berbeda dalam mensikapi bunga tersebut. Ada yang beranggapan bahwa bunga tersebut termasuk riba yang sudah jelas keharamannya, namun tidak sedikit yang beranggapan bahwa bunga atau tambahan tersebut bukan termasuk riba, sehingga hukumnya diperbolehkan.

Para ulama sejak dahulu hingga kini, ketika membahas masalah ini tidak melihat esensi riba guna sekedar mengetahuinya, tetapi mereka melihat dan membahas sambil meletakkan di pelupuk mata serta hati mereka, beberapa praktek transaksi ekonomi guna mengetahui dan menetapkan apakah praktek tersebut sama dengan riba yang diharamkan atau tidak.

Mengenai larangan riba dalam al-Qur'an ataupun as-Sunnah sendiri menimbulkan berbagai pendapat yang berbeda, disebabkan adanya penafsiran akan hakekat serta makna yang sebenarnya akan keharaman riba. Oleh karena itu, untuk mengetahui tentang adanya bunga yang harus

Abdul

Salam

204

1) Provisi adalah bentuk pungutan oleh bank kepada nasabah, yang dimaksudkan sebagai biaya administrasi atau handling charge (afsluitprovisi)

JURNAL EKONOMI SYARIAH INDONESIA, Volume II, No.2 Desember 2012 
dibayarkan oleh nasabah pemakai fasilitas overdraft, apakah bunga tersebut termasuk dalam kategori riba atau bukan, maka perlu kiranya penulis kemukakan akan arti riba dan bagaimanakah bentuk riba yang dilarang oleh al-Qur'an dan as-Sunnah.

Menurut etimologi, riba berarti az-ziyadah, yaitu tambahan atau kelebihan (Warsun, 1997). Sedangkan secara istilah riba adalah sejumlah tambahan yang diberikan oleh orang yang menerima kredit (debitur) kepada pihak yang memberikan kredit (kreditur) sebagai imbalan dikarenakan debitur diberi kesempatan memakai uang tersebut dalam jangka waktu yang telah ditetapkan (As-Sabuni, 1972).

Praktek riba telah ada sebelum Islam, pada jaman jahiliyah. Jazirah arab terletak di jalur perdagangan antara Eropa dan Afrika serta antara India dan Cina, hal ini membuat bangsa arab sangat maju di bidang perdagangan. Praktek riba telah menjadi bagian dari hidup mereka. Unsur bunga merupakan bagian sistem transaksi yang tidak dapat dipisahkan. Bentuk pembungaan yang telah dipraktekkan pada jaman jahiliyah yaitu apabila seseorang meminjamkan harta atau uang kepada orang lain untuk suatu jangka waktu tertentu, kemudian menerima pinjaman pada waktu yang telah ditentukan tersebut, maka ditambah lagi jangka waktu pinjamannya dengan perjanjian bahwa si peminjam bersedia membayar bunga lagi atau bisa disebut dengan sistem bunga-berbunga (Basyir, 1983).

Para ulama berbeda pendapat dalam merinci macam-macam bunga, Ibn Rusyd menyebutkan bahwa riba terdapat pada dua perkara yaitu jual-beli, dan pada jual-beli tanggungan, pinjaman atau lainnya. Riba dalam tanggungan ada dua macam, satu diantara dua macam riba ini sudah disepakati oleh para ulama tentang keharamannya, yaitu riba jahiliyah. Riba dalam jual-beli ada dua macam yaitu riba nasi'ah dan riba tafadhul (Rusyd, tt). Al-Jaziri membagi riba atas riba nasi'ah dan riba fadal (aljaziri, tt). Pembagian seperti ini banyak dipergunakan oleh para ulama, antara lain Ali-as-Sayis dan as-Sabuni dalam kitab tafsir masing-masing (as-Sayis, 1953).

Riba nasi'ah adalah kelebihan yang diperoleh oleh pemberi pinjaman dari peminjam (debitur) sebagai imbalan dari pengunduran batas waktu (Basyir, 1983). Riba nasi'ah sering disebut riba jahiliyah dan disebut juga riba qardi, karena hal ini terjadi dalam hutang-piutang, sedangkan riba fadal adalah tambahan yang diperoleh oleh seseorang sebagai hasil pertukaran dua barang sejenis (al-Maragi, tt). Menurut Sayyid Sabiq adalah pertukaran uang dengan uang, makanan dengan makanan disertai dengan adanya tambahan. Riba Fadal sering disebut riba buyu' karena terjadi dalam jual-beli. Riba nasi'ah diharamkan karena mengandung unsur-unsur eksploitasi atau pemerasan dari orang hanya terhadap orang

Mekanisme Kliring miskin dan di lain pihak meniadakan nilai tolong-menolong dan nilai kegunaan dalam bermu'amalah serta memberi jalan pemupukan jiwa materialistis dalam hidup bermasyarakat. Sedangkan riba fadl dilarang untuk menutup meluasnya riba dikalangan masyarakat (Basyir, 1983).

Al-Qur'an dan Hadis telah mempersoalkan riba dengan ringkas dan jelas. Bahkan sudah menerangkan pula hikmah yang terkandung di 
dalamnya. Meskipun demikian, pendapat para alih tentang riba masih berbeda-beda.

\section{Dari Segi Pemberian Sanksi}

Kliring merupakan suatu bentuk muamalat dalam penyelesaian transaksi hutang-piutang antar bank, dimana bank sebagai wakil nasabah membantu transaksi hutang-piutang yang dilakukan oleh nasabahnya. Kliring adalah pertukaran warkat atau data keuangan elektronik baik antar bank maupun antar nasabah yang hasilnya diselesaikan pada waktu tertentu (Widjanarko, 2003).

Kliring merupakan suatu kegiatan perbankan yang didasarkan kepada kepercayaan. Maka tidak jarang nasabah menyalahgunakan kepercayaan yang diberikan oleh pihak bank seperti penarikan cek kosong. Penarikan cek kosong biasanya terjadi karena nasabah sebagai pemegang cek mengalami hambatan dalam pembayaran hutang menurut kesepakatan. Terhadap penarikan cek kosong yang dilakukan oleh nasabah (muwakkil) maka bank (wakil) akan memberikan sanksi kepada nasabah berupa penutupan rekening dan memasukkan dalam daftar hitam, namun sebelum memberikan sanksi kepada nasabah karena penarikan cek kosong ini, bank melakukan beberapa hal yaitu :

a). Penolakan pada cek kosong yang diterima bank :

1. Bank akan melakukan penolakan pembayaran atas cek kosong. Penolakan cek kosong ini disertai surat tanda penolakan dari cek kosong tersebut dan dikembalikan kepada pemegangnya untuk diselesaikan dengan pemiliknya.

2. Memberikan 1 lembar tanda penolakan cek kosong kepada BI.

3. Dengan dikembalikannya cek kosong kepada pemegang untuk diselesaikan dengan penarik. Penyelesaian pembayaran cek kosong tidak lagi harus diselesaikan melalui bank dan dengan demikian dana atau saldo rekening penarik (jika ada) tidak diblokir.

b). Tindakan yang dilakukan oleh bank dalam hal ini terjadi penolakan cek kosong:

1. Bank melakukan peringatan tertulis kepada pemegang rekening yang bersangkutan untuk setiap penolakan cek kosong agar perbuatan itu jangan terulang lagi.

2. Nasabah yang melakukan penarikan cek kosong tiga kali berturut-turut dalam jangka waktu dua bulan, rekening harus segera ditutup.

3. Penutupan rekening ini harus dilaporkan kepada kantor pusat BI Jakarta. Bagian lalu-lintas pembayaran giral bagi bank-bank yang berkantor di wilayah kerja kantor pusat BI, atau kepada kantor cabang BI setempat bagian. Bank yang berada di luar wilayah Jakarta cabang BI akan segera meneruskan laporan penutupan rekening dari bank-bank tersebut kepada pusat BI.

4. Atas laporan tersebut, BI menyusun daftar hitam gabungan penarikan cek kosong. Laporan itu diedarkan kepada semua bank umum atau bank pembangunan di Indonesia. Bank-bank tidak diperkenankan mengadakan perjanjian hubungan rekening koran dengan orang atas badan usaha yang namanya tercantum dalam daftar hitam tersebut. Prosedur dan syarat rehabilitasi dari daftar hitam ditentukan oleh BI.

Abdul

Salam

206 
Di dalam Wakalah terutama dalam akad yang dikabulkan hukum akad akan kembali kepada orang yang mewakilkan, sebab merekalah yang sebenarnya merupakan pihak-pihak yang berkepentingan dalam akad yang terjadi. Dalam wakalah terutama dalam akad, tentunya ada perbuatan-perbuatan yang mesti dilakukan guna tercapainya akad. Misalnya menyerahkan barang yang dijual belikan oleh penjual, penerimaan harga barang oleh penjual, mengembalikan barang yang dijualbelikan karena cacat, hak membatalkan atau melangsungkan dan sebagainya.

Dalam hubungannya dengan perwakilan. Oleh karena yang langsung mengadakan akad adalah wakil, maka hak-hak akad kembalinya kepada wakil bukan kepada muwakkil (orang yang mewakilkan). Dalam perjanjian jual beli yang diwakilkan misalnya seorang menjadi wakil kedua belah pihak, wakil menyerahkan barang dan dia juga yang menerima pembayaran. Apabila barang yang bersangkutan cacat, dia pula yang mengembalikannya. Ketentuan ini berlaku dalam akad yang mungkin disandarkan kepada wakil sebagai yang langsung menangani.

Berbeda dengan akad yang tidak mungkin disandarkan kepada wakil, meskipun dia menanganinya, misalnya dalam akad nikah, talak tebus dn sebagainya. Hak-hak akad kembali kepada yang mewakilkan. Dengan demikian dalam akad nikah misalnya, istri tidak dapat menggugat mahar kepada orang yang pernah menjadi wakil suami dalam akad nikah, gugatan mahar harus langsung ditujukan kepada suami, sebab akad nikah tidak mungkin disandarkan dari wakil yang menangani akad atas nama orang lain.

Dalam hal di atas, maka penulis dapat paparkan hal-hal sebagai berikut. Dalam pelaksanaan kliring wakil bertindak secara langsung. Dalam transaksi bayar membayar hutang, namun dalam hal terjadinya penolakan cek kosong. Maka bank akan memberi surat penolakan dan dilampiri cek tersebut dan dikembalikan kepada pemegang cek dengan penariknya. Maka dalam hal ini kliring termasuk dalam kategori akad yang tidak disandarkan kepada wakil.

Perwakilan dapat terjadi karena pemberian jasa tanpa imbalan dari wakil. Dan dapat juga merupakan penjualan jasa dari wakil. Dalam mekanisme kliring ini bank (wakil), menjual jasa kliring ini kepada nasabah muwakkil. Maka bank dalam hal ini berhak menentukan syaratsyarat yang akan dilaksanakan dalam akad wakalah, dalam hal ini kliring.

Maka dapat dikatakan bahwa bank dapat melakukan tindakan penarikan cek kosong yang dilakukan oleh nasabah karena nasabah telah melakukan kesalahan yaitu mengingkari akad. Dalam pemberian sanksi ini, bank melakukan beberapa tahapan sebelum memberikan sanksi yang

Mekanisme Kliring sesungguhnya seperti tindakan peringatan, dalam hal ini tindakan bank sebagai muwakkil dapat dibenarkan oleh Hukum Islam. Kebijakan ini diambil berdasarkan realita yang terjadi, nasabah pengguna jasa ini sebagaian besar adalah wirausaha yang kehidupannya hanya mengandalkan hasil usahanya dan sangat membutuhkan jasa ini terutama dalam transaksi bayar membayar.

JURNAL EKONOMI SYARIAH INDONESIA, Volume II, No.2 Desember 2012 
Sehingga jika usaha yang dilakukan itu mendapat untung (maju) dan tidak terjadi kredit macet maka nasabah dapat melaksanakan pembayaran hutangnya sesuai dengan waktunya dan dapat melaksanakan apa yang menjadi ketentuan bank. Namun apabila terjadi kredit macet, atau usahanya sedang merugi (lesu) maka nasabah tidak dapat melunasi hutangnya tepat pada waktunya. Disebabkan hasil yang didapat belum ada atau belum mencukupi untuk membayar.

Tindakan bank selaku pemberi jasa ini (transfer atau kliring), dengan memberi peringatan dan tenggang waktu nasabah untuk menyelesaikan transaksinya, termasuk pada tindakan memberikan pertolongan kepada nasabah (debitur). Dikarenakan nasabah di dalam transaksinya mengalami kesukaran untuk mengembalikan hutangnya (kredit) tepat pada waktunya. Pemberian peringatan dan pemberian waktu tersebut akan menjadikannya diselamatkan Allah SWT di hari kiamat dari segala beban.

Ditegaskan di dalam hadis Nabi :

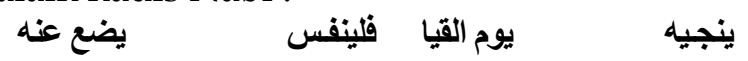

Solusi Islam dalam menangguhkan pembayaran, lebih ditekankan pada suatu kondisi debitur yang kesulitan dalam menunaikan kewajiban yaitu melunasi hutangnya (kredit) dikarenakan adanya kredit macet (dana yang belum datang) atau karena kebutuhan lain yang tingkat kepentingannya lebih mendesak untuk segera ditunaikan. Kebutuhan dalam terminologi usul fiqih adalah suatu keadaan yang menghendaki agar seseorang melakukan perbuatan yang tidak menurut hukum yang semestinya berlaku, karena adanya kesempitan dan kesukaran atau dengan kata lain seseorang melakukan perbuatan menyimpang dari hukum yang semestinya itu adalah untuk menghindari kesukaran dan kesulitan (Abdurahman, 1976). Konsep ini dipertegas berdasarkan firman Allah surat al-Baqarah ayat 185 dan kaidah fiqih.

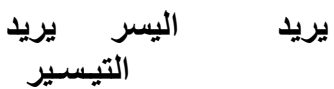

Kaidah ini menegaskan bahwa syari'at Islam dapat dilaksanakan oleh mukallaf di mana saja yakni dengan memberikan keringanan (takhfif) pada seorang mukallaf yang sedang mengalami kesempitan atau kesukaran. Ulama usul fiqih membagi sebab-sebab keringanan (takhfif) menjadi 7 macam, yaitu :

1. Bepergian (safar)

2. Terpaksa (ikrah)

3. Lupa (nisyan)

4. Kurang mampu (nuqsan)

5. Sakit (maradh)

6. Tidak tahu (jahl)

7. Mewabahnya musibah (ummul balwa) (al-Khallaf, tt).

Nasabah pengguna jasa bank, dikarenakan kebutuhannya yang sangat banyak terpaksa menangguhkan dalam melakukan kreditnya. Kondisi ini dapat menjadi sebab baginya mendapat keringanan (takhfif) yang diberikan nasabah pengguna jasa bank termasuk dalam kategori takhfif yang ditawarkan oleh Islam. Takhfif dalam Hukum Islam dibagi menjadi beberapa macam, yaitu : 
1. Takhfif Isqath (keringanan berupa pengguguran).

2. Takhfif Tauqish (keringanan berupa pengurangan).

3. Takhfif Ibdal (keringanan berupa penggantian).

4. Takhfif Taqdim (keringanan berupa mendahulukan sesuatu yang belum waktunya).

5. Takhfif Ta'khir (keringanan berupa mengakhirkan sesuatu yang telah datang waktunya).

6. Takhfif Taqhyir (keringanan berupa perubahan sesuatu yang telah diatur dengan aturan tertentu).

7. Takhfif Tarkhish (keringanan berupa pemberian kemurahan atau rukhsah) (Faturrahman, 1993).

Nasabah diberi penangguhan untuk ditutup rekening gironya masuk dalam kategori takhfif turkhish. Adanya takhfif yang ditetapkan sebab terpaksa (ikrah) tidak dapat masuk pada kategori takhfif isqath. Hal ini berdasarkan kaidah :

Islam menganjurkan agar nasabah dan bank saling menghormati serta memenuhi perjanjian yang telah disepakati bersama. Sedangkan tentang pemberian sanksi yang dilakukan bank berupa penutupan rekening dan juga pencantuman dalam daftar hitam nasabah yang melakukan penarikan cek kosong, dapat dibenarkan dengan alasan-alasan sebagai berikut :

1. Bank telah memberi waktu dan peringatan kepada nasabah, yaitu nasabah selama enam bulan tidak diperkenankan menarik cek sebanyak 3 kali (yang urutan pemberian peringatan dapat dibaca di Bab III).

2. Dengan pemberian sanksi ini, bank mengharapkan agar nasabah tidak mengulangi lagi tindakan itu.

3. Dengan pemberian cek kosong tersebut membuat tidak lancarnya kredit, disamping membuat kelancaran lalu-lintas pembayaran terganggu.

4. Penetapan tentang sanksi ini telah diatur oleh BI sebagai bank sentral disamping bank pemerintah.

Kaidah yang sesuai dengan masalah ini adalah syaddu aż-żari'ah. Hal ini memungkinkan bank menerapkan sanksi terhadap nasabah yang melakukan cek kosong, guna mencegah terganggunya pembayaran dalam sistem perbankan.

\section{E. KESIMPULAN}

Setelah penulis mengadakan penelitian tentang mekanisme kliring pada perbankan konvensional, maka dapat ditarik beberapa kesimpulan bahwa kliring yang merupakan salah satu jasa perbankan konvensional, adalah pertukaran warkat atau data keuangan elektronik baik antar bank

Mekanisme Kliring maupun antar nasabah yang perhitungannya diselesaikan pada waktu tertentu. Dalam hal ini Bank Indonesia yang menjadi penyelenggara kliring yang berwenang mengatur lalu lintas pembayaran giral atau bank yang ditunjuk oleh BI. Dalam pelaksanaan kliring ini bank menjadi wakil nasabah dalam menyelesaikan transaksi hutang yang dilakukan oleh para nasabah apalagi dengan adanya warkat kliring luar wilayah, 
memungkinkan penyelesaian transaksi hutang antar kota. Warkat-warkat yang dipergunakan dalam kliring antara lain cek, BG, wesel, nota kredit dan nota debet.

Dalam pelaksanaan kliring, nasabah mewakilkan kepada lembaga perbankan untuk menyelesaikan transaksi hutang mereka. Perwakilan demikian dalam Islam diistilahkan dengan wakalah yang bersandar pada akad dari para pihak yang berakad, yang tentunya tidak terlepas dari beberapa sultan al-iradah, di mana aqid dapat mengemukakan berbagai macam syarat yang mereka kehendaki dalam batas-batas kerelaan para pihak, termasuk dalam pemberian fee terhadap wakil, yang dalam hal ini para wakil tersebut adalah lembaga perbankan yang ditunjuk. Dalam hal pemakaian jasa kliring ini, akad terjadi ketika nasabah datang ke bank untuk menjadi nasabah giro, dan bank sebagai muwakkil menyerahkan slip yang harus diisi nasabah. Dan nasabah diberitahu oleh bank hak dan kewajibannya sebagai nasabah giro. Setelah nasabah mengisi formulir tersebut dan mengetahui hak dan kewajibannya serta kedua belah pihak menyepakatinya maka akad wakalah telah terjadi.

Adapun overdraft adalah salah satu jenis fasilitas yang ditawarkan oleh lembaga perbankan konvensional kepada nasabah tertentu yang dipandang lembaga perbankan berhak memperoleh fasilitas tersebut, sehingga bukan merupakan fasilitas yang bisa diperoleh setiap nasabah. Jadi jenis fasilitas ini sangat rentan dengan KKN (korupsi, kolusi dan nepotisme) karena persyaratan yang ditentukan oleh lembaga perbankan untuk memperoleh fasilitas ini hanya tergantung pada kebijakan perbankan yang tidak lepas dari unsur subyektifitas, sehingga pada akhirnya tidak jarang menjadi bumerang bagi lembaga perbankan yang bersangkutan.

Sedangkan dalam praktek overdraft terdapat unsur-unsur yang menyebabkan jasa ini larang yaitu unsur eksploitasi, unsur kesempatan dalam kesempitan, dan unsur ketidakadilan. Disamping itu dalam pemberitahuan laporan akhir bulanan bank sering memberikan laporan yang kurang jelas, seperti perubahan besarnya bunga pinjaman yang diketahui nasabah sebesar 5\% tetapi dalam laporan akhir bulan menjadi $6 \%$. Jasa overdraft ini merupakan suatu kegiatan terselubung yang dilarang pemerintah, karena dari setiap transaksi yang dilakukan, Bank yang memberi jasa ini tidak membayar kepada BI sebagai bank sentral Indonesia, hal ini dibuktikan dengan tidak digunakannya materai. Hal yang paling mendasar, transaksi ini biasanya hanya dilakukan antara direktur bank dengan nasabahnya tanpa diketahui oleh pegawai bank yang lain.

Dalam pemberian sanksi kepada nasabah terhadap cek kosong berupa pemberhentian dari nasabah giral dan dimasukkan dalam daftar hitam oleh suatu bank, dapat dibenarkan hukum Islam, dikarenakan sebelum menjatuhkan sanksi, bank telah memberikan peringatan agar nasabah tidak menarik cek kosong lagi. Apabila bank tidak memberikan sanksi, maka penggunaan cek kosong tersebut akan mengganggu lalu lintas pembayaran giral dan mengakibatkan terganggunya administrasi bank tersebut dalam hal pembukuan.

Abdul

Salam 


\section{Daftar Pustaka}

Abdurrahman, Asjmuni, 1976, Kaidah-Kaidah Fiqh, cet. 1, Bulan Bintang, Jakarta

Al-Abidin, Zain, 1993, Al-Asybah wa an-Nazair 'Ala Mazhab Abi Hawfah an$N u^{\prime} m a n$, cet I, Dar al-Kutub al-Ilmiah, Beirut

Ali As-Syairazi, Ibn, Ibrahim, Ishaq, Abi, Imam, t.t, Fil Figh Al-Mazhab Imam Syafi'i, Toha Putra, Semarang

Al-Maraqi, Mustafa, Ahmad, t.t Tafsir al-Maragi, : Maktabah ra kat'ba'ah Mustafa al Habi wa Awladuh, Mesir

Anwar, Muhammad, 1982, Tindak Pidana di Bidang Perbankan, cet. 2, Almni, Bandung.

Anwari, Achmad, 1981, Rekening Koran suatu Bentuk Penyimpanan Uang di Bank yang Bebas dan Rahasia, Balai Aksara, Jakarta

Ash-Shiddieqy, Hasbi, 1984, Pengantar Fiqih Muamalat cet.2 , Bulan Bintang, Bandung

As-Sabuni, Ali, Muhammad, 1972, Rawai 'al bayan Tafsir Ayat Ahkam alQur'an,: Jar al-Qur'an al-Karim, Makkah

As-Sayis, Ali, 1953, Tafsir Ayat Ahkam I, Murba'ah Muhammad Ali Sabib Wa Amaduh, Mesir

Az-Zuhaili, Wahbah, 1989, Al-Figh al-Islami wa Adillatuhu, Dar al-Fikr, Beirut

Basjir, Azhar, Ahmad, 1993, Asas-Asas Hukum Mu'amalat, edisi revisi, Perpustakaan Fak. Hukum UII, Yogyakarta

Fatchurrahman, 1993, Dasar-Dasar Pembinaan Hukum Figh Islam, cet. 3, AlMa'arif, Bandung

Hareon, Nasroen, 1984, Fiqih Muamalat. Cet.2, Gaya Media Pratama, Jakarta

Mas'adi, Ghufran, 2002, Figh Muamalah Kontekstual, cet.1, PT Raja Grafindo Persada, Jakarta

Nugroho, Adi, Tjipto, 1979, Perbankan Masalah Praktikum Tata Tehnis, Pradnya Paramita, Jakarta

Rizal, Ahmad, 1992, Operasional Bank, edisi I Universitas Terbuka, Yogyakarta

Rusyd, Ibnu, t.t, Bidayatul al-Mustahid wa Nihayah al-Muqtasid, Dar al-Ihya al Kutub al-Arabiyah

Sinungan, Muchdarsyah, 1991, Uang \& Bank, cet 3, Rineka cipta, Jakarta

Siregar, Muchdarsyah, 1984, Dasar-Dasar dan Tehnik Manajemen Kredti, Bina Aksara, Jakarta

Subagyo, 2002, Bank dan Lembaga Keuangan Lainnya, STIE YKPN, Yogyakarta

Mekanisme

Kliring

211
Suhendi, Hendi, 2002, Fiqih Muamalat, Raja Grafindo Persada, Jakarta

Taswan, 2003, Akuntansi Perbankan Transaksi dalam Valuta Rupiah, edisi revisi, UPP AMP YKPN, Yogyakarta

Taswin, 1997, Akuntansi Perbankan Transaksi dalam Valuta Rupiah, cet.1 UPP AMP YKPN, Yogyakarta

Triyanto, Duddy, 1996, Mengenal Dunia Perbankan, Andi Offset, Yogyakarta 
Warson, Ahmad, 1997, Al-Munawwir Kamus Arab-Indonesia, edisi kedua, cet 14. Pustaka Progressif, Surabaya

Wawancara dengan Syidad Qori (karyawan Bank Konvensional ) di Yogyakarta 2012

Widjanarko, 2003 Hukum dan Ketentuan Pembukuan di Indonesia, edisi VI Pustaka Utama Grafiki, Jakarta 